DOI:

10.1038/nrg2251

\title{
Chain reaction
}

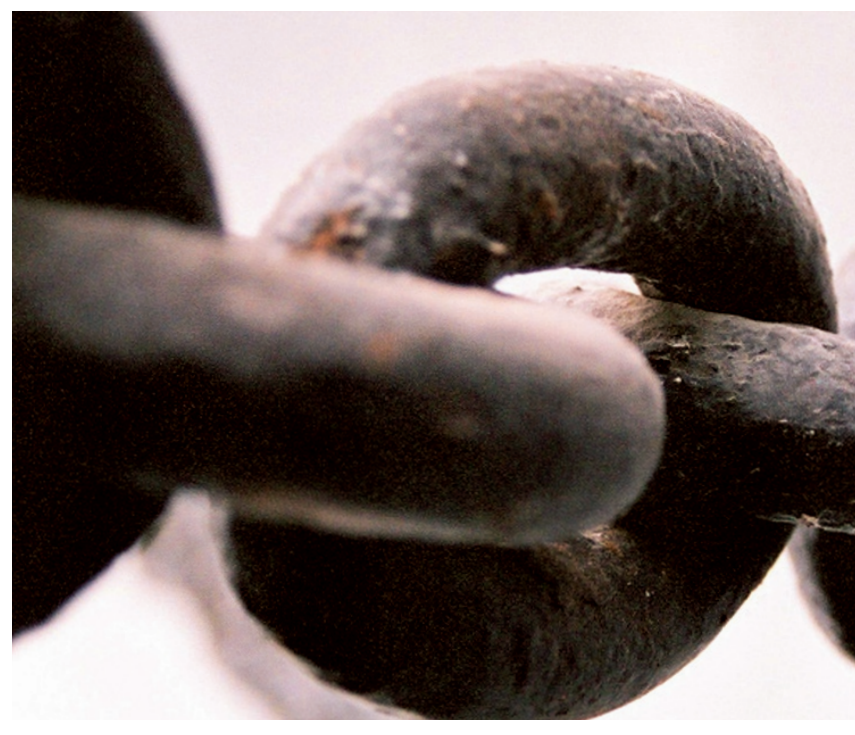

Today, it would be difficult to conceive of a biology laboratory

Today, it would be difficult to conceive of a biology laboratory without a polymerase chain reaction apparatus'the PCR machine'. without a polymerase chain reaction apparatus-'the PCR machine'. Standard molecular practices that we take for granted, such as creating constructs for expressing tagged proteins, amplifying genes from minute samples for cloning and introducing mutations into genes, would be a completely different story, a much more complicated one, without the advent of PCR.

This technique, which has revolutionized biological laboratory research, was first developed about two decades ago. Yet in 1971, in a Journal of Molecular Biology report, Har Gobind Khorana and colleagues had already described a process called repair replication for synthesizing short DNA duplexes and single-stranded DNA by polymerases. This report outlined several features that are hallmarks of PCR, but fell short of an experimental test. It predicted, for example, that the DNA duplex would have to be denatured to single strands, that an excess of primer to template would be required to overcome secondary structures generated by singlestranded template and that, following completion of the reaction by DNA polymerase, the cycle would have to be reinitiated if the template duplex had renatured.

However, it took another almost 17 years before PCR, as we know it, was described. Kary Mullis and Fred Faloona, in a 1987 paper in Methods in Enzymology, experimentally defined the basic steps of PCR. The authors speculated about the potential applications of the method, many of which are now routine molecular biology procedures. Interestingly, 2 years before this landmark report was published, Norman Arnheim and colleagues demonstrated the power of PCR as a diagnostic tool by showing that such an approach could be used to rapidly amplify the $\beta$-globin sequence from clinical samples to determine whether it possessed the mutation for sickle cell anaemia .

\section{It was not until 1988 that Henry} Erlich and colleagues described the use of a thermostable DNA polymerase from Thermus aquaticus, which was a key innovation that allowed annealing and extension at high temperatures. This crucial improvement did away with the need to replenish the enzyme after each cycle, increased specificity, yield and sensitivity, allowed the process to be used to generate longer products and, finally, paved the way for its automation. PCR, as we know it, was born.

Sowmya Swaminathan, Senior Editor, Nature Cell Biology

ORIGINAL RESEARCH PAPERS Kleppe, K.,

Ohtsuka, E., Kleppe, R., Molineux, I. \& Khorana, H. G. Studies on polynucleotides. XCVI. Repair replications of short synthetic DNAs as catalyzed by DNA polymerases. J. Mol. Biol. 56, 341-361 (1971) | Saiki, R. K. et al. Enzymatic amplification of $\beta$-globin genomic sequences and restriction site analysis for diagnosis of sickle cell anemia. Science 230, 1350-1354 (1985) | Mullis, K. B. \& Faloona F. A. Specific synthesis of DNA in vitro via a polymerase-catalyzed chain reaction. Meth. Enzymol. 155, 335-350 (1987) | Saiki, R. K. et al. Primer-directed enzymatic amplification of DNA with a thermostable DNA polymerase. Science 239, 487-491 (1988) 